\title{
Youth, Religion and Democracy After the Arab Uprisings: Evidence from the Arab Barometer
}

\author{
Michael Robbins \\ Princeton University and the University of Michigan
}

he Arab uprisings of 2011 left an indelible mark on the region. As Long-standing
presidents fell in four countries, many wondered if a wave of democratization
might be sweeping the region. This early optimism soon faded as countries as protests were violently suppressed in Bahrain and subsequently Libya, Syrian and Yemen fell into civil war.

This narrative of the failure of the uprisings to yield substantial political reform overlooks an important period of political openness that was found in Tunisia and Egypt, the two countries where the protest movement began. From 2011 to 2013, both countries witnessed unprecedented periods of political freedom. For the first time, citizens in both countries experienced free and open elections, enjoyed a greater ability to speak freely, and watched as long-standing Islamist opposition groups formally entered the political sphere.

Evidence from around the world shows that ordinary citizens are likely to respond to the changes in their political environment through a process of political learning. ${ }^{1}$ Thus, a critical question, particularly in the cases of Egypt and Tunisia is to what extent, if any, did the political changes as a result of the Arab uprisings change the attitudes of toward democracy and political Islam in the initial years after the uprisings? Has there been a shift in attitudes with citizens becoming more likely to support democracy or wanting a different role for religion in politics in response to these events? And, to what degree, if any, have changes in attitudes varied by country context? Although a watershed event of this nature may affect citizens of all ages, the focus of this research is on citizens ages 18-29 as existing evidence suggests that youths are most likely to engage in political learning since they are less likely than older generations to have fixed political and social preferences. ${ }^{1}$

\footnotetext{
${ }^{1}$ Richard Rose, William Mishler, and Christian Haerpfer, Democracy and its alternatives: Understanding post-communist regimes, Baltimore: Johns Hopkins University Press, 1998.

Yu-tzung Chang, Yun-han Chu, and Chong-Min Park, "Authoritarian Nostalgia in Asia." Journal of Democracy 18(2007): 66-80.

Michael Bratton, Robert Mattes, and Emmanuel Gyimah-Boadi, Public Opinion, Democracy, and Market Reform in Africa, Cambridge: Cambridge University Press, 2005.
} 
This article compares the changes over time in attitudes of youth in Egypt and Tunisia, two countries that experienced dramatic political changes in the aftermath of the Arab uprisings. The primary comparison is the change in attitudes over time within each country; views of youths just after the respective revolutions are compared with views of a similar cohort two years after these events to determine how the Arab uprisings affected views toward democracy and political Islam in the two aforementioned countries. The second comparison is how the shifts in attitudes during this period differed between youths in the two countries. This comparison provides insight into how responses to the events of the Arab uprisings varied by country context.

The basis for this examination is public opinion data from the Arab Barometer, a project that conducts face-to-face nationally representative surveys of men and women aged 18 and older across the Middle East and North Africa. ${ }^{2}$ Data presented and analyzed in this article come from the second and third waves of the project. ${ }^{3}$ In Egypt, the second wave was conducted in June-July 2011, about four months after the fall of President Hosni Mubarak. ${ }^{4}$ In Tunisia, the survey was conducted in September-October 2011, about eight months after the ouster of President Zine al-Abidine Ben Ali and shortly before the National Constituent Assembly elections. ${ }^{5}$ In Egypt, the third wave was carried out in March-April 2013 while in Tunisia, the third wave was carried out in February 2013. ${ }^{6}$

\footnotetext{
${ }^{2}$ For additional information about this project, please visit htttp://arabbarometer.org

${ }^{3}$ Like any source of data collection, the use of surveys has advantages and disadvantages. An important benefit is that, based on the survey design, the findings can be generalized to the entire population. However, one limitation of this method is that it is not always clear how respondents understand the questions being asked. As noted later in this article, the survey asks about attitudes toward democracy but does not provide a definition of this concept, meaning respondents may have differing interpretations of what this word means. This problem may affect other types of analysis where the investigator and the subject have different understandings of a term. However, in open-ended or semi-structured interviews, such differences can be probed more easily than in a closed-ended instrument like that used as part of the Arab Barometer.

${ }^{4}$ The second wave survey in Egypt is a national probability sample design and was conducted face-toface in Arabic based on a complex sample design that included stratification and clustering. The survey was stratified by governorate and further stratified by urbanity. Interviews were distributed proportional to population size (PPS). In each stratum, sampling blocks, which are defined by CAPMAS, were selected using PPS and represent the primary sampling unit. Within each sampling block, clusters of 10 households were randomly selected. The survey was conducted by al-Ahram Center for Strategic Studies. The sample size is 1,219 .

${ }^{5}$ The second wave survey represents a national probability design and was conducted face-to-face in Arabic using a complex sample design that included stratification and clustering. The survey was stratified by governorate and urbanity. Interviews were distributed proportional to population size (PPS). Within each stratum, delegations were selected using PPS. Within each delegation, sectors were selected using PPS and within each sector blocks were selected using simple random sampling. Each block contained 10 households. Within the household, individuals were randomly selected using a Kish table informed by quotas for age and gender. The survey was conducted by Sigma Conseil and included 1,196 respondents.

${ }^{6}$ The second and third wave surveys are not panel surveys. Each was carried out using a similar methodology to the second wave surveys. However, in Egypt, the third wave survey was conducted by the MADA Center for Media and Communication Strategies and had a sample size of 1,196. In Tunisia, the third wave was again conducted by Sigma Conseil and included 1,199 respondents.
} 
Despite contextual differences between Egypt and Tunisia, the factors leading to the Arab uprisings and the events that followed the Arab uprisings shared a number of key similarities in these two countries. Youth ages 18-29 in both countries had grown up within a closed political system that suddenly opened following the downfall of a longstanding leader. Similarly, both experienced relatively free and fair elections for the first time in late 2011, elections that yielded victories for the main Islamist party in each country, which both happened to be political wings of two branches of the transnational Muslim Brotherhood. By 2013, security conditions in both countries had declined, and economic conditions had not changed substantially from 2011. Thus, for the purpose of understanding political learning among youths, the comparison of those in Egypt and Tunisia can approximate a natural experiment.

Two years after the Arab uprisings, youth in both Egypt and Tunisia had sufficient experience to reflect on the recent events and revise their beliefs about both democracy and the role of religion in politics. Despite a similar sequence of events in each country, the effect on the attitudes of youth varied dramatically. Support for democracy in Egypt was virtually unchanged, while youth in Tunisia became dramatically more concerned about potential problems associated with democracy. Meanwhile, youth in Egypt demonstrated a significant decline in support for political Islam, while levels of support for political Islam in Tunisia remained largely unchanged.

These distinct processes suggest that the process of revising beliefs is linked to factors beyond the direct result of elections; instead, youth make a complex assessment based on the assignment of blame, or credit, based on the behavior of political elites. This finding suggests a retrospective model of assessment based on factors related to the transition. Additionally, given differences between the two countries, these findings suggest that how youth change their attitudes varies significantly on the basis of specific domestic factors. Thus, although a number of accounts of the Arab uprisings highlight the importance of international factors in explaining outcomes following the Arab uprisings, ${ }^{7}$ it is clear that domestic factors ultimately had a much greater effect on the political trajectory of each country, at least in explaining the process of political learning for youth.

\footnotetext{
${ }^{7}$ Henry E. Hale, "Regime Change Cascades: What we have learned from the 1848 revolutions to the 2011 Arab uprisings," Annual Review of Political Science 16(2013): 331-353.

Michael Herb, "The People Want to Fall of the Regime... or Not: Explaining the diffusion of the Arab Spring," Georgia State University, May 21, 2014.

Marc Lynch, The Arab Uprising: The unfinished revolutions of the new Middle East. New York: PublicAffairs, 2013.

Justus Bamert, Fabrizio Gilardi, and Fabio Wasserfallen, "Learning and the diffusion of regime contention in the Arab Spring," Research \& Politics 2(2015): 1-9.

Michael Robbins and Mark Tessler, "The Effect of the Arab Spring on Support for Democracy: Evidence from an unplanned quasi-experiment," Paper presented at annual meetings of the American Political Science Association, New Orleans, August 30-September 2, 2012.

Stephen M. Saiderman, "When Conflict Spreads: Arab Spring and the limits of diffusion." International Interactions: Empirical and Theoretical Research in International Relations 38(2012): 713-722.
} 
Examining these changes through multivariate analysis provides additional insight into these issues. In Egypt, youth tended to view both democracy and political Islam instrumentally, supporting or opposing each based on their position in society. Attitudes were highly unstable during these two years as youth received new information. By contrast, the position of Tunisian youth mattered much less in predicting support for democracy or political Islam, implying that support is more evenly spread throughout society. Changes in opinion followed without a clear class or political division, a different process of updating than that seen in Egypt. It appears Tunisian youth, whether rich or poor, were more likely to change their attitudes based on perceptions related to the future of the country rather than based on their particular position within Tunisian society. These differences may, at least in part, help explain the different trajectories between the two countries. Tunisia, while facing a myriad of political, social and economic challenges since 2011, maintains a democratic system, while Egypt has returned to an authoritarian system.

These results build on, but also challenge, the existing literature on democratic transitions. Tunisia does not fit the model where citizens change their beliefs primarily on demographic and personal circumstances ${ }^{8}$ while Egypt fits this model only partially. Similarly, the electoral outcome of the founding election appears to play less of a role in determining attitudes toward democracy as some existing accounts suggest. ${ }^{\text {? }}$

The article begins with an overview of the respective political and religious histories of both Egypt and Tunisia. It then examines popular support among youth for both democracy and political Islam at the time of the revolution, including relevant sociodemographic differences within each country. The next section examines changes in youth attitudes in each country as a result of the events that followed the revolution, including a comparison of these changes between countries to understand how different social and political contexts may account for the differences in the nature of change between the two countries. To further understand the reasons for these changes, the next section examines support using a multivariate model. The final section compares and contrasts these experiences and highlights the contributions of this research to the broader literature on political transitions and support for democracy.

\section{Background on Egypt and Tunisia}

Prior to the Arab uprisings, neither Egypt nor Tunisia had a substantial history with democracy. However, there are important historical and cultural differences, especially relating to their respective experiences with the relationship between religion and public

\footnotetext{
${ }^{8}$ Richard Rose, William Mishler, and Christian Haerpfer, Democracy and its alternatives: Understanding post-communist regimes, Baltimore: Johns Hopkins University Press, 1998.

Yu-tzung Chang, Yun-han Chu, and Chong-Min Park, "Authoritarian Nostalgia in Asia." Journal of Democracy 18(2007): 66-80.

${ }^{9}$ Michael Bratton, Robert Mattes, and Emmanuel Gyimah-Boadi, Public Opinion, Democracy, and Market Reform in Africa, Cambridge: Cambridge University Press, 2005.

Kenneth Benoit, "Models of Electoral System Change," Electoral Studies 23(2004): 363-389.
} 
life. Egypt is a deeply religious country with a long history of Islamic activism and powerful state religious institutions. Al-Azhar University in Cairo is globally considered the center of Sunni Islamic learning. Although nationalized after independence, Al-Azhar remains a powerful center for religious education in the world, and plays a central role in mediating the official version of Islam in Egypt.

Beyond Al-Azhar, Jamal Abdel-Nasser, Egypt's President from 1956-1970, and his associated Free Officer's Movement, sought to bring other forms of religious authority under state control. In 1952, reforms brought waqf, or religious endowments, under the control of the state through the Ministry of Endowments. The regime also sought to weaken the ulema by abolishing sharia courts in 1955 and placing personal status laws under the jurisdiction of civil courts. ${ }^{10}$

Meanwhile, popular Islam also has a long history in Egypt. Emerging out of Islamic revival movements from the turn of the $20^{\text {th }}$ century, Hassan al-Banna founded the Muslim Brotherhood in 1928. The Brotherhood quickly spread across Egypt and throughout the Muslim world. Since the 1940s, the Brotherhood has been a key political actor, oftentimes in conflict with the regime. In the 1950s and 1960s, President Gamal Abdel Nasser violently suppressed the organization, forcing it largely underground. Although not legally allowed to participate in elections, Brotherhood candidates ran for parliament as members of other parties or independents in most elections since the 1980s, winning as many as 88 of 442 seats (20 percent) in the 2005 elections.

Compared with Egypt, religion has played a lesser role in Tunisian political life since independence from France. At the time of independence in 1956, long-standing religious institutions had been weakened yielding no equivalent to Al-Azhar in Egypt. To a significant extent, this was due to the role of French colonization, particularly French secular education, in creating a more secularized elite in Tunisia. Tunisia's first postindependence president, Habib Bourghiba, was also hostile toward independent religious authorities playing a significant role in political life, ${ }^{11}$ favoring a state role in promoting religious values rather than the traditional ulama. ${ }^{12}$ To further weaken the religious elite, Bourghiba eliminated the system of waqf and created a unified justice system that brought traditional religious judges into the secular state system. ${ }^{13}$ Subsequent Tunisian leaders also sought to crush religious institutions, believing that modernization required religious authorities to play a minimal role in public life. ${ }^{14}$

\footnotetext{
${ }^{10}$ It should be noted that civil courts continued to ground their judgments in religious law.

${ }^{11}$ Sophie Bessis and Souhayr Belhassen. Les femmes du Maghreb. Tunis: Cérès, 1992.

12 The ulema is a body of religious scholars who are recognized as experts in Islamic law and jurisprudence.

${ }^{13}$ Tad Stahnke and Robert C. Blitt, "The Religion-State Relationship and the Right to Freedom of Religion or Belief: A comparative textual analysis of the constitutions of predominately Muslim countries," Georgetown Journal of International Law 36(2005): 947-1078.

${ }^{14}$ Michael Robbins and Lawrence Rubin, "The Rise of Official Islams," American Political Science Association Annual Meetings, San Francisco, September 3-6, 2015.
} 
Like Egypt, a popular Islamist movement emerged in Tunisia as a key opposition group to the regime, although its influence and levels of support were far less than that of the Muslim Brotherhood in Egypt. The alNahda Movement, taking inspiration from the Muslim Brotherhood movement, came to prominence following the 1979 Iranian Revolution. The Tunisian government banned the party from participating in the 1989 elections, and the party remained illegal until after the 2011 "Jasmine Revolution."

Although historical conditions vary, political events in Egypt and Tunisia that followed the Arab uprisings share a number of key similarities. In Tunisia, the protests began in the regional capital of Sidi Bouzid in December 2010. As trade unions joined the movement, demonstrations quickly spread across the country, eventually reaching the national capital of Tunis. ${ }^{15}$ Following continued unrest demanding the resignation of President Zine al-Abidine Ben Ali, the long-standing leader eventually fled into exile on January 14 .

Following Ben Ali's departure, the transitional government promised free and fair elections for the National Constituent Assembly to be held later in the year. Elections held on October 23, 2011 resulted in a victory for alNahda, which won a plurality of all votes with 37 percent. The second largest party was the Congress for the Republic (CPR or al-Mo'tamar), a center-left secular party, which won nine percent of the vote. Ettakatol, a social democratic party, won the third largest vote share with seven percent. Together, these three parties formed a governing coalition commonly referred to as the "Troika government," which alNahda led under Prime Minister Ali Laarayedh.

Debate over the constitutional changes was protracted in Tunisia. At the time of the February 2013 Arab Barometer survey, the government had not yet agreed upon the basics of a draft text for a new constitution. ${ }^{16}$ Moreover, the security situation had declined across the country shortly before the survey was fielded, with a rise in extremist violence in rural areas and the high profile assassinations of political figures such as Chokri Belaid, an opposition leader with the Democratic Patriots' Movement, on February 6, 2013.

Egypt followed a relatively similar trajectory. Large-scale protests began in Cairo on January 25, 2011. As these protests spread throughout the country and were compounded by labor strikes, pressure on the regime of President Mohammed Hosni Mubarak mounted. On February 11, Vice President Omar Suleiman announced that Mubarak had resigned and that power was transferred to the Supreme Council of the Armed Forces (SCAF).

One of SCAF's first actions was to dissolve the parliament and call for new elections by the end of the year. Parliamentary elections were eventually held in three rounds, beginning on November 28, 2011 and concluding on January 11, 2012. Islamist parties

\footnotetext{
15 Vickie Langhor, "Labor Movements and Organizations," in The Arab Uprisings Explained, edited by Marc Lynch, 180-200. New York: Columbia University Press, 2014.

${ }^{16}$ After more than two years of discussions, the document was ratified on January 26, 2014. 
dominated the elections, with the Muslim Brotherhood-affiliated Freedom and Justice Party (FJP) winning a plurality of 37.5 percent, followed by al-Nour, a Salafist party, at 27.8 percent. Presidential elections followed, with the final round held in June 2012. The result was a narrow victory for Mohamed Morsi of the FJP over Ahmed Shafik, an independent who had been appointed as prime minister by President Mubarak on January 31, 2011 and considered by the revolutionaries to be one of the flool (remnants) of the Mubarak's regime.

With control of both the presidency and the parliament, the FJP drafted a new constitution. Amid demonstrations about the slow pace of political change, the eventual document was approved by the Constituent Assembly, a body dominated by Islamists, after a marathon session on November 30, 2012. Among other changes, the new constitution increased the prominence of religious law in guiding legislation. Meanwhile, just a week earlier, President Morsi issued a decree granting himself broad powers above any court as the "guardian of Egypt's revolution," sparking fears that he would become a new dictator, although he soon partially reversed course. ${ }^{17}$

As in Tunisia, security remained a major problem in Egypt. Ongoing attacks in the Sinai were common as was increased lawlessness in Cairo and other major cities. Combined with continued high levels of unemployment and weak economic growth, ${ }^{18}$ public opinion shifted strongly against Morsi and the FJP by the time of the 2013 Arab Barometer survey. ${ }^{19}$

In summary, between the first and second waves of the Arab Barometer, youths in both Egypt and Tunisia experienced the first free and fair elections in their country's history and lived through a period of increased political openness. At the same time, youth in both countries lived under governments led by Islamist parties for roughly 18 months, although the political strength of the FJP in Egypt exceeded that of alNahda in Tunisia.

\section{Youth and Support for Democracy}

At the time of the Arab uprisings, youths across the Middle East and North Africa region strongly supported democracy. This finding also holds true for Tunisia (78 percent) and Egypt (73 percent) with roughly three-quarters of those ages 18-29 agreeing or strongly agreeing with the statement "despite its problems, democracy is the better than other political systems." Despite the massive changes that occurred in Egypt from 2011 to 2013 , there was virtually no change ( -1 percentage point) in support for democracy. Support did decline slightly among youths in Tunisia, however, falling to 72 percent ( -6 percentage points) by 2013.

\footnotetext{
${ }^{17}$ David Kirkpatrick and Mayy El Sheikh, "Citing Deadlock, Egypt's Leader Seizes New Power and Plans Mubarak Retrial," New York Times, November 22, 2012.

${ }^{18}$ Mohsin Khan, "The Turnaround of the Egyptian Economy in 2014," Atlantic Council, January 16, 2014.

${ }^{19}$ 1-Ahram. 2013. "Morsi's Popularity Wanes 10 Months into Egypt's Presidency: Poll." Ahram Online, May 14.
} 
A trend concealed by the relatively stable levels of support for democracy is found in differences in how youth in Egypt and Tunisia understand democracy. Previous work has demonstrated that understandings of democracy differ widely across Arab publics, with many citizens viewing democracy in economic rather than in political terms. ${ }^{20}$ Unsurprisingly, youths in Egypt and Tunisia - who prior to the Arab uprisings had little to no direct experience with democracy - also have varied conceptions of the primary characteristics of democratic rule.

In 2011, youths in these two countries had very different understandings of democracy. Three-quarters of Egyptian youth identified the most important feature of democracy as an economic characteristic, including 33 percent saying it is providing basic necessities to all citizens and 30 percent who say it is a narrowing of the income gap between the rich and the poor. Given economic conditions at the time, with many citizens being poor and marginalized compared with the success of crony capitalists tied to the regime, these sentiments are understandable. Likely, Egyptian youth believed democracy would bring about economic equality to their country.

By contrast, in 2011, the majority of Tunisian youths understood democracy as primarily a political outcome. Fully six-in-ten said its most important feature was political, including the ability to change governments through elections (33 percent), followed by the right to criticize the government or the equality of political rights among citizens (13 percent).

The respective experiences of the political changes in each country, subsequently, had opposite effects on youth. In Egypt, there was a massive change in conceptions of democracy among youth just two years after the uprisings. In 2013, just over 55 percent of the participants understood democracy in economic terms, representing a 19 percentage point decline. At that time, youth were more than three times more likely to understand democracy as the ability to criticize those in power ( 5 percent versus 17 percent), and more than two-and-a-half times as likely to say it was about elections ( 6 percent versus 16 percent).

In Tunisia, however, the opposite trend holds: youths became 11 points more likely to think of democracy in economic terms than before. The most significant decrease was a 15 percentage point decline in the percentage who say democracy is primarily defined as regular elections (33 percent versus 18 percent), which was distributed more-or-less equally across the economic categories. Thus, in the years after the Arab uprisings, Tunisian youth came to believe democracy was much more than simply the ability to vote in free and fair elections.

\section{Concerns About Democracy}

Support for democracy, broadly defined, may conceal growing concerns about whether democracy is significantly better than other types of political systems. The Arab Barometer asks respondents about three potential outcomes that may be associated with democracy. First, it is sometimes claimed that democracies are not good at managing the

\footnotetext{
${ }^{20}$ Amaney Jamal, Mark Tessler and Michael Robbins, "New Findings on Arabs and Democracy," Journal of Democracy 23(2012), 89-103.
} 
Table 1

\section{Concern about Democracy $\%$ who agree or strongly agree that...}

\begin{tabular}{|c|c|c|c|c|}
\hline & \multicolumn{2}{|c|}{ Egypt } & \multicolumn{2}{|c|}{ Tunisia } \\
\hline & 2011 & 2013 & 2011 & 2013 \\
\hline Democracy is not good at managing the economy & 17.7 & 21.0 & 21.3 & 37.1 \\
\hline Democracy is indecisive & 21.7 & 26.1 & 22.4 & 50.8 \\
\hline Democracy is not good at maintaining stability & 21.7 & 21.8 & 19.9 & 42.4 \\
\hline
\end{tabular}

economy. Second, some say that democracies are indecisive. Third, it is often said that democracies are not good at maintaining order. At the time of the Arab uprisings, youths in both Egypt and Tunisian had few concerns about the potential problems associated with democracy. In fact, no more than a quarter of those ages 18-29 agreed or strongly agreed with any of these assertions (see table 1).

Most likely, the lack of concern about democracy was the result of two factors. First, few youths had any direct experience with democratic governance. Given the varying ways youth define democracy, ${ }^{21}$ it appears that many likely associated democracy as a solution to many of the problems without fully understanding many of the potential weaknesses of this system. Second, youths could also reflect on their recent experience with authoritarian governments in both countries. In both cases, economic outcomes were poor before the uprisings and leaders had not acted decisively to address many ills in society. Moreover, the example of the Arab uprisings strongly implied that authoritarian regimes were unable to maintain security. Given that authoritarian regimes were unable to successfully solve these problems, few youths were likely to worry that a democratic system would share these problems. ${ }^{22}$

Despite the political upheavals in Egypt in the two years after the uprisings, concerns about democracy increased only slightly. For example, youth were five points more likely to say the economy runs poorly, four points more likely to say democracy is indecisive, and equally likely to say democracy is not good at maintaining security. At most, 26 percent agreed or strongly agreed that democracy suffers from any of these problems.

By contrast, concern about problems associated with democracy increased dramatically in Tunisia from 2011 to 2013. Associating Tunisia's ongoing economic problems with

\footnotetext{
${ }^{21}$ Results from these surveys reveal that there is no single accepted definition of democracy among youth in either country. More than 10 percent of youth in each country list the most important feature of democracy as being one of each of the following features: the opportunity to change the government through elections; freedom to criticize the government; narrowing the gap between rich and poor; provision of basic items such as food and housing; equality of political rights; and eliminating corruption. ${ }^{22}$ Michael Robbins and Mark Tessler, "The Effect of Elections on Public Opinion towards Democracy," Comparative Political Studies 45(2012): 1255-1276.
} 
the new political system, in 2013 youths were 16 points more likely to say the economy does not run well under democracy than they were two years earlier. The gap is even larger for whether democracy is indecisive: in 2013, fully half ( 51 percent) of those ages 18-29 agreed or strongly agreed that democracy is indecisive, an increase of 29 percentage points from 2011. Similarly, youth were 22 points more likely to say democracies are not good at maintaining stability in 2013 compared with shortly after the Jasmine Revolution.

In sum, youth in Egypt do not appear to strongly link the challenges associated with the post-revolutionary period to problems with democracy. By contrast, Tunisian youth have strongly associated the economic and political dislocations with fundamental limitations of a democratic system. As a result, they have changed their opinions about democracy and are cognizant of some potential weaknesses. Thus, although youth in Egypt and Tunisia are equally likely to support democracy, their processes of political learning have varied since the Arab uprisings.

\section{Youth and Religion}

Most youth in Egypt and Tunisia do not describe themselves as "religious" but rather as "somewhat religious." At the time of the Arab uprisings, about a third (32 percent) of Egyptians ages 18-29 said they were religious, compared with the majority (64 percent) who said they were somewhat religious. Just one-in-ten Tunisian youth considered themselves to be religious (10 percent) while again the majority ( 58 percent) said they were moderately religious.

Self-identified levels of religiosity remained more-or-less constant in Egypt from the time of the revolution in 2011 until 2013. However, in Tunisia the percentage that considered themselves as religious more than doubled to 23 percent. Notably, the increase in religiosity was due almost entirely to an increase in levels of personal piety in urban areas. This change could be attributable to the changing political climate: alNahda's victory and the perceived increasing strength of religion across the region may account, at least in part, for this shift.

One of the long-standing explanations to account for support for political Islam, defined here as a desire for religion to have a significant role in the political arena, ${ }^{23}$ is the economic grievance hypothesis. According to this account, frustrated citizens, particularly elite youth lacking employment, turn to religion as the answer. Seeking an alternative to the status quo, they turn their support to groups that espouse giving Islam a role in politics. $^{24} \mathrm{~A}$ second account highlights the opportunity structure political Islam

\footnotetext{
${ }^{23}$ Are Knudsen, "Political Islam in the Middle East", Chr. Michelsen Institute Development Studies and Human Rights Working Paper, 2003.

${ }^{24}$ Mark Tessler, "The Origins of Popular Support for Islamist Movements," in Islam, Democracy, and the State in North Africa edited by John Entelis, 93-126. Bloomington, IN: Indiana University Press, 1997.

Mehmet Tansel Demir, "Political Islam: Background, Development and Prospects for the Future," Working paper, 2005.
} 
Table 2

\section{Support for Political Islam \\ \% who agree or strongly agree that...}

\begin{tabular}{lllllll}
\hline & \multicolumn{2}{c}{ Egypt } & & \multicolumn{2}{c}{ Tunisia } \\
\cline { 2 - 3 } & $\mathbf{2 0 1 1}$ & $\mathbf{2 0 1 3}$ & $\mathbf{2 0 1 1}$ & $\mathbf{2 0 1 3}$ \\
\hline It would be Better if More Religious People Held Public Office & 47.9 & 23.0 & & 22.6 & 35.2 \\
Men of Religion should have Influence over Decisions of Government & 37.3 & 20.3 & & 23.5 & 26.5 \\
\hline
\end{tabular}

provides within an otherwise closed system. Members of the middle class without elite connections can take part in organizations that offer them political and social opportunities for advancement. ${ }^{25}$

In light of the limited social and economic opportunities available to youth in both Egypt and Tunisia, these theories then suggest that support for political Islam should be relatively high in both cases. Yet, despite the post-revolutionary electoral results, evidence from the Arab Barometer suggests that support was not overly high among this generation. In both countries, no more than half of those ages 18-29 favored political Islam.

The Arab Barometer measures support for political Islam based on whether or not a respondent agrees with a number of statements. Two of these items are used in the analysis that follows. The first statement reads: "Your country is better off if religious people hold public positions in the state." 26 The second is: "Religious leaders should have influence over government decisions." 27

At the time of the Arab uprisings, Egyptian youth were more supportive of giving religion a role in the political sphere than their Tunisian counterparts (see table 2). For example, nearly half ( 48 percent) of Egyptian youth said it would be better if more religious people held public office. By contrast, fewer than a quarter (23 percent) of Tunisians said the same. The results for whether religious leaders should have influence over government decisions were similar: 47 percent of Egyptian youth favored this arrangement compared with just 24 percent of Tunisian youth. Notably, support for political Islam is fairly consistent across segments of Tunisian society, with men and women, more and less educated, and urban and rural youths are about as likely to favor Islam in each country.

\footnotetext{
${ }^{25}$ Janine Clark, Islam, Charity, and Activism: Middle-Class Networks and Social Welfare in Egypt, Jordan and Yemen, Bloomington, IN: Indiana University Press, 2004.

Tarek Masoud, Counting Islam, Cambridge: Cambridge University Press, 2014.

${ }^{26}$ In Arabic, the term religious people is translated as al-mutadinnun which could be interpreted by respondents in different ways.

${ }^{27}$ In Arabic, the term "religious leaders is translated as rijāl al-dīn (a'imah, khutabā', qusāwasa). 
The events of the next two years altered perceptions among youth toward political Islam in both countries, but not in the same manner. In Egypt, support for political Islam declined dramatically from 2011 to 2013. Two years after the Arab uprisings, just 23 percent of citizens ages 18-29 said it would be better if more religious people held public office, a decline of 25 percentage points. Similarly, there was a 17 percentage point decline in the percentage of youth who said men of religion should have say over decisions of government.

By contrast, Tunisian youth became far more likely to say that their country would be better off if more religious people held public office, rising to 35 percent, a 12 percentage point increase. However, Tunisians ages 18-29 remained about as likely, a three point increase, to say men of religion should have a say over decisions of government. Thus, there is no increase in support for a strong role for religion in politics. Instead, it appears some Tunisian youth, perhaps frustrated by a perception of ongoing corruption under a religiously affiliated government, favored having religious individuals, often believed to be less corrupt, in public office.

\section{Multivariate Analysis}

The above sections have demonstrated that the events that followed the Arab uprisings had a profound effect the public opinion of youth in both countries. However, additional analysis is required to establish the precise factors underlying these shifts in youth attitudes and why they varied to such an extent between the Egyptian and Tunisian cases. Accordingly, multivariate models are developed to establish which variables, holding others constant, explain the differences between the attitudes of youth in both countries and how these factors changed between 2011 and 2013.

In the period following the uprisings, religion, politics and the democratic process became significantly intertwined. Islamist parties won the greatest vote share in both Tunisia and Egypt; meaning youths may have understood the effect of these changes through multiple lenses. First, following relatively free and fair elections, youth could attribute outcomes, whether positively or negatively, to the new, more democratic, political system. Their evaluations of officials, and their policies, chosen through the ballot box in free and fair elections might have led them to change their beliefs about democracy.

Alternatively, given that Islamist parties, the Muslim-Brotherhood affiliated Freedom and Justice Party in Egypt and alNahda in Tunisia, led both governments following the elections, youths may attribute outcomes less to the political system and more to the parties the system empowered. As such, political learning among the youth cohort may reflect perceptions of parties that raise the banner of Islam in politics. By extension, youths may change their attitudes toward the ideology underlying these parties, meaning political Islam.

In all likelihood, their process of updating takes both elements into account, although the degree to which attribution is to the democratic system versus its results 
may vary widely. To empirically evaluate the determinants of attitudes toward both democracy and political Islam, a single model is constructed and tested on two dependent variables. The first dependent variable measures concern about democracy as a system of governance while the second measures support for political Islam.

A comparison of the determinants of these models for both countries and years can provide deeper insight into the shifts in public opinion among youth during a turbulent political period. In the analysis, 2011 can be used as a baseline for analysis. In both countries, the surveys were conducted before the elections where Islamist parties took power or work on new constitutions had begun. This point can be compared with results from 2013, at which point Islamist parties had won elections and shaped the new political order.

\section{Dependent Variables}

As previously described, support for democracy as a form of governance is high in both Egypt and Tunisia and went largely unchanged between the two years. Yet, concern about democracy exhibits greater variation over time, particularly in Tunisia where it increased dramatically between 2011 and 2013. Given that these items may better capture degrees of support for democracy than a more generalized measure, they are used to construct the dependent variable by combining them into a single additive index. ${ }^{28}$ The underlying concept being captured is concern about the democratic system. Overall, the three correlate strongly across both countries and both waves of surveys, generally at a level of 0.65 or greater. In a single instance, in the third wave in Tunisia, the correlation between two of the items is only 0.53 . The index yielded a 10-point scale where 1 was coded as having no significant concerns about democracy and 10 was coded as having a high degree of concerns about democracy (see table 3).

The second dependent variable is support for political Islam. The two aforementioned items are used to construct an additive index ranging from 1 to 7 , with 1 representing low support for political Islam and 7 representing high support (see table 4). The two items do not correlate as highly as the items for democracy, instead ranging from 0.41 to 0.61 by country and year. Although a single item could be used, the latent concept being examined - support for political Islam - includes both items. Thus, the two are combined despite the moderate correlation.

\section{Independent Variables}

A number of independent variables were included to evaluate the factors leading youth to hold attitudes more or less supportive of the dependent variables, and to allow for a comparison of the changes in these determinants between 2011 and 2013. First, evaluations of the government were included. Evidence suggests

\footnotetext{
${ }^{28}$ Although it would be possible to generate an index through latent variable analysis or factor analysis, an additive index creates a measure that is consistent across space and time, which is preferable in the analysis that follows.
} 
Table 3

Concern about Democracy Index

\begin{tabular}{lrrrr}
\hline & \multicolumn{2}{c}{ Egypt } & \multicolumn{2}{c}{ Tunisia } \\
\cline { 2 - 5 } & $\mathbf{2 0 1 1}$ & $\mathbf{2 0 1 3}$ & $\mathbf{2 0 1 1}$ & $\mathbf{2 0 1 3}$ \\
\hline Lowest & 25.1 & 19.3 & 13.2 & 15.5 \\
2 & 2.8 & 6.6 & 4.8 & 2.2 \\
3 & 10.7 & 7.6 & 5.1 & 4.3 \\
4 & 34.5 & 31.3 & 42.1 & 19.3 \\
5 & 5.6 & 11.6 & 12.9 & 12.9 \\
6 & 6.3 & 5.1 & 7.4 & 16.7 \\
7 & 6.6 & 5.8 & 7.4 & 16.7 \\
8 & 5.3 & 3.3 & 1.3 & 5.2 \\
9 & 1.6 & 1.5 & 1.9 & 0.9 \\
Highest & 1.6 & 8.0 & 3.9 & 6.4 \\
\hline
\end{tabular}

that views of government can affect levels of support for democracy after founding elections in newly democratic or democratizing systems. ${ }^{29}$ Similarly, since Islamist parties took power in both countries, support for political Islam may be linked to the performance of the government. The measure used to capture attitudes toward the government is:

Generally speaking, how would you evaluate the performance of the government (the cabinet) in carrying out its tasks and duties?

1. Very good

2. Good

3. Neither good nor bad

4. Bad

5. Very bad

Second, views toward elections could influence attitudes toward both democracy and support for political Islam. At its most basic level democracy is about elections. ${ }^{30}$ Yet, not all elections are equal, as citizens in Egypt and Tunisia, where elections were held for many years before the uprisings, are aware. Instead, the quality of elections, whether they are free and fair, is a critical element of evaluating democracy. ${ }^{31}$ However, those who support parties or candidates that lose elections are less likely to evaluate

\footnotetext{
${ }^{29}$ Michael Bratton, Robert Mattes, and Emmanuel Gyimah-Boadi, Public Opinion, Democracy, and Market Reform in Africa, Cambridge: Cambridge University Press, 2005.

30 Joseph Schumpeter, Capitalism, Socialism and Democracy, London: Allen and Unwin, 1976.

${ }^{31}$ Michael Robbins and Mark Tessler, "The Effect of Elections on Public Opinion towards Democracy," Comparative Political Studies 45(2012): 1255-1276.
} 
Table 4

Support for Political Islam Index

\begin{tabular}{lrrrrr}
\hline & \multicolumn{2}{c}{ Egypt } & \multicolumn{2}{c}{ Tunisia } \\
\cline { 2 - 3 } \cline { 5 - 6 } & $\mathbf{2 0 1 1}$ & $\mathbf{2 0 1 3}$ & $\mathbf{2 0 1 1}$ & $\mathbf{2 0 1 3}$ \\
\hline 1 & 11.7 & 25.3 & 15.5 & 21.7 \\
2 & 7.6 & 11.5 & 7.3 & 11.2 \\
3 & 17.5 & 32.8 & 43.2 & 26.9 \\
4 & 20.8 & 17.1 & 19.8 & 19.7 \\
5 & 20.2 & 7.9 & 11.3 & 13.7 \\
6 & 5.9 & 1.3 & 0.9 & 3.6 \\
7 & 6.4 & 4.3 & 2.1 & 3.2 \\
\hline
\end{tabular}

them as free and fair, and perhaps, in turn, less likely to support democracy. ${ }^{32}$ Similarly, if an individual believed that Islamist parties or candidates won the election illegitimately, he or she might change his or her attitudes about political Islam. The following variable is used to measure the quality of elections: ${ }^{33}$

In general, how would you evaluate the last parliamentary elections that were held on (Day, Month, Year)? $?^{34}$

1. They were completely free and fair

2. They were free and fair, with some minor breaches

3. They were free and fair, with some major breaches

4. They were not free and fair

Beyond political changes, many citizens hoped for changes to an economic system they saw as unequal. Another factor that could influence feelings toward both democracy and political Islam is the degree to which the government is working to crack down on corruption. Anger at endemic corruption was a key concern in the Arab uprisings region-wide. Since, on average, democracies tend to be less corrupt than authoritarian systems ${ }^{35}$ citizens may have perceived this change to be a key benefit of democracy. Similarly, Islamist parties, claiming a religious basis, are often perceived as being less corrupt. However, if democratically elected Islamist governments did not sufficiently tackle

\footnotetext{
32 Devra Moehler, "Free and Fair or Fraudulent and Forged: Elections and legitimacy in Africa," Afrobarometer Working Paper No. 55 (December), 2005.

33 This variable is only included in the second model to evaluate the degree to which respondents believed that the first election after the uprisings was free and fair. There is minimal variation in this variable for elections prior to the Arab uprisings, as the vast majority of youth say elections under the old regime were not free and fair.

${ }^{34}$ In Tunisia the question asked specifically about the National Constituent Assembly elections.

35 Ivar Kolstad and Arne Wiig, "Does Democracy Reduce Corruption?" CMI Working Paper 4, 2011.
} 
corruption, it could lead to a decline in support for democracy, political Islam, or both. The following item is used to measure how the government is doing on corruption:

In your opinion, to what extent is the government working to eliminate corruption in your country?

1. To a great extent

2. To a medium extent

3. To a limited extent

4. Not at all

Beyond corruption, many may look to broader economic changes as a result of the changed political system. Evaluating the degree to which economic factors affect support for democracy and support for political Islam takes two forms. First, youth may change their beliefs based on their personal economies, in effect becoming pocketbook voters regarding satisfaction with democracy and the government. ${ }^{36}$ Alternatively, it is possible they take a sociotropic view based on overall economic conditions. ${ }^{37}$ If democracy is not seen to improve these outcomes, concern about the system of governance may increase. ${ }^{38}$ Similarly, if youth did not see improvement in economic outcomes they may blame the ideology underlying the parties in power. These two economic dimensions are measured by the following variables:

I will read you some statements related to your household income. Which of these statements comes closest to describing your bousebold income? ? $^{39}$

1. Our household income covers our expenses well and we are able to save.

2. Our household income covers our expenses without notable difficulties.

3. Our household income does not cover our expenses and we face some difficulties in meeting our needs.

4. Our household income does not cover our expenses and we face significant difficulties in meeting our needs.

How would you evaluate the current economic situation in your country?

1. Very good

2. Good

\footnotetext{
${ }^{36}$ Michael Bratton and Robert Mattes, "Learning about Democracy in Africa: Awareness, Performance and Experience," Afrobarometer Working Paper No. 31, 2003.

${ }^{37}$ Donald Kinder and D. Roderick Kiewiet, "Sociotropic Voting: The American Case," British Journal of Political Science 11(1981): 129-161.

${ }^{38}$ Richard Rose, William Mishler, and Christian Haerpfer, Democracy and its alternatives: Understanding post-communist regimes, Baltimore: Johns Hopkins University Press, 1998.

39 This measure is more preferable for youths than an individual income question. Many in this age cohort are continuing with their educations or living with their families. Thus, a pure income measure is less likely to accurately represent the true status of the individual. Moreover, because many youths do not know the amount of income their family receives, there is a high degree of missing data for the family income variable. Using this proxy, although an imperfect measure, remains preferable to these two alternatives.
} 


\section{Bad \\ 4. Very bad}

Finally, given the election results, trust in the main Islamist party, the Muslim Brotherhood-affiliated Freedom and Justice Party in Egypt and alNahda in Tunisia, may have a significant impact on both support for democracy and political Islam. If citizens do not trust those elected to lead the government in free elections, support for democracy may decline. Similarly, levels of trust in a party who takes up the banner of Islam would be expected to have major implications on support for political Islam.

Beyond these items, a number of standard demographic controls are included in the model: age, education, sex and urban-rural residence. The model is run separately for both countries for both years. Ordinary least squares regression is employed with robust standard errors to account for the multistage sampling design.

\section{Support for Democracy}

In Egypt shortly after the uprising, concern about democracy varied across a number of demographic groups (see table 5). On the political variables, ratings of government and how the government is doing eliminating corruption are not significant at standard levels. This finding is not entirely surprising, given the transitional nature of the government in June 2011. These results suggest that youth who were better off during the previous regime, and more likely to be disadvantaged by a new order, harbored greater concerns about democratic governance.

Economic variables are also linked to views of democracy. Youths who came from wealthier families, defined as those who say their incomes are sufficient for their needs, were more skeptical of this system of governance than their poorer counterparts. Similarly, those who say that the national economy is doing better are also more likely to harbor concern about democracy. Interestingly, youth with lower levels of trust in the Muslim Brotherhood were also more concerned about potential problems associated with democracy. Likely, these individuals were concerned about democracy translating into a victory of Islamists.

Overall, these results suggest that concerns about democracy were higher among secular elites than among youths from other social classes. Poorer youth in Egypt who were alienated by the previous regime and more trusting in the Brotherhood harbored far fewer concerns about this system of governance shortly after the revolution. Thus, it appears that many of Egypt's youth expected democracy to bring about improved political and economic outcomes without bringing significant problems of its own.

By 2013, however, judgments about democracy had changed in important ways. Roughly three months before President Mohamed Morsi was deposed, political factors were much more influential in determining the commitment of Egyptian youth to democracy. Holding all else equal, those who said that the government was doing a good job were significantly more likely to harbor doubts about the democratic process. Given findings from other democratizing countries, this result is surprising; evidence from Eastern Europe and sub-Saharan Africa suggests that these individuals should have 
Table 5

OLS Regression with Concern About Democracy as Dependent Variable

\begin{tabular}{|c|c|c|c|c|}
\hline \multirow[b]{2}{*}{ Variable } & \multicolumn{2}{|c|}{ Egypt } & \multicolumn{2}{|c|}{ Tunisia } \\
\hline & $\begin{array}{c}2011 \\
n=289\end{array}$ & $\begin{array}{c}2013 \\
\mathbf{n}=216\end{array}$ & $\begin{array}{c}2011 \\
n=275\end{array}$ & $\begin{array}{c}2013 \\
n=158\end{array}$ \\
\hline Higher Rating of National Economy & $\begin{array}{l}0.465 \\
(0.194)^{* * *}\end{array}$ & $\begin{array}{c}0.384 \\
(0.316)\end{array}$ & $\begin{array}{c}0.191 \\
(0.187)\end{array}$ & $\begin{array}{c}-0.071 \\
(0.338)\end{array}$ \\
\hline Higher Rating of National Government & $\begin{array}{c}0.099 \\
(0.125)\end{array}$ & $\begin{array}{l}0.878 \\
(0.202)^{* * * *}\end{array}$ & $\begin{array}{c}0.029 \\
(0.153)\end{array}$ & $\begin{array}{c}0.160 \\
(0.242)\end{array}$ \\
\hline Government Eliminating Corruption & $\begin{array}{c}0.183 \\
(0.187)\end{array}$ & $\begin{array}{c}0.108 \\
(0.216)\end{array}$ & $\begin{array}{c}0.086 \\
(0.182)\end{array}$ & $\begin{array}{r}-0.016 \\
(0.227)\end{array}$ \\
\hline Higher Trust in the FJP/alNahda & $\begin{array}{l}-0.248 \\
(0.115)^{* * *}\end{array}$ & $\begin{array}{l}-0.486 \\
(0.231)^{* *}\end{array}$ & $\begin{array}{c}0.057 \\
(0.118)\end{array}$ & $\begin{array}{c}0.070 \\
(0.214)\end{array}$ \\
\hline Higher Rating of Last Parliamentary Election & & $\begin{array}{c}-0.028 \\
(0.152)\end{array}$ & & $\begin{array}{r}-0.185 \\
(0.205)\end{array}$ \\
\hline Rural & $\begin{array}{r}-0.068 \\
(0.280)\end{array}$ & $\begin{array}{c}0.731 \\
(0.340)^{* *}\end{array}$ & $\begin{array}{r}-0.228 \\
(0.305)\end{array}$ & $\begin{array}{r}-0.109 \\
(0.467)\end{array}$ \\
\hline Higher Education & $\begin{array}{c}-0.176 \\
(0.299)\end{array}$ & $\begin{array}{c}0.695 \\
(0.517)\end{array}$ & $\begin{array}{c}-0.258 \\
(0.293)\end{array}$ & $\begin{array}{r}-0.190 \\
(0.457)\end{array}$ \\
\hline Higher Income & $\begin{array}{l}0.541 \\
(0.159)^{* * * *}\end{array}$ & $\begin{array}{c}0.462 \\
(0.193)^{* *}\end{array}$ & $\begin{array}{c}0.314 \\
(0.142)^{* *}\end{array}$ & $\begin{array}{c}0.052 \\
(0.207)\end{array}$ \\
\hline Female Sex & $\begin{array}{c}0.048 \\
(0.271)\end{array}$ & $\begin{array}{c}-0.626 \\
(0.339)^{*}\end{array}$ & $\begin{array}{c}-0.356 \\
(0.268)\end{array}$ & $\begin{array}{r}-0.074 \\
(0.430)\end{array}$ \\
\hline Older Age & $\begin{array}{c}-0.036 \\
(0.041)\end{array}$ & $\begin{array}{c}-0.027 \\
(0.053)\end{array}$ & $\begin{array}{c}-0.011 \\
(0.040)\end{array}$ & $\begin{array}{c}0.015 \\
(0.061)\end{array}$ \\
\hline
\end{tabular}

Note: Table presents coefficient $(\beta)$ estimates with standard errors in parentheses.

${ }^{*}$ Statistically significant at .1 level. ${ }^{* *}$ Statistically significant at .05 level. ${ }^{* * *}$ Statistically significant at .01 level.

fewer concerns about democracy since they are more supportive of the government. ${ }^{40}$ In Egypt, youth who supported Morsi's government may have become frustrated by the perceived inability of his government to institute its platforms. Challenges from the socalled "deep state" may partially account for this result. ${ }^{41}$

Somewhat surprisingly, judgments about democracy were not linked with the quality of the previous parliamentary elections in 2011-2012. Although many youths claimed that these elections were not free and fair (39 percent), there is not a strong link between

\footnotetext{
${ }^{40}$ Yu-tzung Chang, Yun-han Chu, and Chong-Min Park, "Authoritarian Nostalgia in Asia." Journal of Democracy 18(2007): 66-80.

Michael Bratton, Robert Mattes, and Emmanuel Gyimah-Boadi, Public Opinion, Democracy, and Market Reform in Africa, Cambridge: Cambridge University Press, 2005.

${ }^{41}$ Momani, Bessma. "In Egypt, 'Deep State' vs. 'Brotherhoodization'." The Globe and Mail, August 21, 2013.
} 
this perception and a loss of faith in democracy. Compared with findings from SubSaharan Africa, ${ }^{42}$ this outcome is also surprising.

Again in 2013 economic variables are linked with levels of concern about democracy, although the relationships differ from those observed in the second wave data. For example, the economic well-being of youths is significant at standard levels, but the relationship reversed from 2011. In 2013, poorer Egyptian youth were more concerned about the potential problems of democracy. Likely, these individuals were frustrated by the inability of this system to bring rapid improvements to their lives. Meanwhile, views about the Egyptian economy overall were no longer strongly linked to attitudes toward democracy.

Again, judgments about the Muslim Brotherhood remain closely tied to judgments about democracy. Youth who trust the Brotherhood to a lesser extent remain more concerned about democracy than those who are more trusting of this organization.

In 2013, demographic variables are also linked with attitudes about democracy. Youth living in rural areas, where potential reforms brought about by the transition are least likely to be felt by the population, are more concerned about democracy. Additionally, young men are more likely to be concerned with democracy.

Overall, these findings suggest a process of significant political learning about democracy among Egyptian youths based on the events that followed the Egyptian uprising. Although young elites were initially most concerned about democracy, just two years later it was poorer youth, including those living in marginalized areas, who were more likely to worry about the benefits from democracy. Most likely, the lack of expected economic development altered this relationship, as the new government could not effectively address the economic dislocations that followed the uprising. Additionally, satisfaction with the current government, as opposed to judgments about the quality of the electoral process, came to play a greater role in assessing the problems associated with democracy. In other words, concerns about democracy appear to have grown among Egyptian youth who feared this system was unlikely to bring about desired reforms. Meanwhile, concern among young elites was relatively less, perhaps for similar reasons: the inability of FJP party to bring about dramatic changes combined with its flagging popularity may have led to increased faith in democracy among the wealthier and more politically connected youths.

\section{Tunisia}

The results in Tunisia offer a stark contrast to those from Egypt. In 2011, concern about democracy remained fairly low in Tunisia and was relatively evenly spread across all segments of its youth. Political variables and judgments do not offer significant explanatory power regarding commitment to democracy.

\footnotetext{
${ }^{42}$ Devra Moehler, "Free and Fair or Fraudulent and Forged: Elections and legitimacy in Africa," Afrobarometer Working Paper No. 55 (December), 2005.
} 
For economic variables, only a single one is significantly related to views of democracy at standard levels of significance. As in Egypt, youths from wealthier families were somewhat more concerned about the implications of democracy than those from poorer backgrounds. Thus, there is some evidence that those from more elite families may also have feared the implications of democracy on their well-being. However, no significant difference is found for views of the Tunisian economy overall, in contrast to the results in Egypt. Additionally, perceptions about corruption are also not linked with concerns about democracy.

Again, in contrast to Egypt, levels of trust in the main Islamist party, alNahda, are unrelated to concern about democracy. Thus, it appears that fear of an Islamist victory at the ballot box did not alter the views of Tunisians about democracy overall. Also, as with Egypt in 2011, no basic demographic differences explain differences in levels of concern about democracy.

As noted above, concern about democracy in Tunisia increased dramatically between 2011 and 2013. Yet, again in stark contrast to Egypt, views of democracy were more-or-less evenly spread across youths from all backgrounds. In fact, there are no significant differences across all variables included in the model.

As in Egypt, wealthier Tunisian youth were no longer more concerned about democracy in 2013. The fact that other economic variables also remain insignificant is similar to Egypt, however, suggesting that economic concerns play a lesser role in explaining commitment to democracy, despite findings from Eastern Europe. ${ }^{43}$

Similarly, no variation is found in concern about democracy based on ratings of the government. This non-result may be due, in part, to the fact that alNahda brought two secular parties into the Troika government. This coalition of parties may have blunted the link between specific government policies and judgments about democracy. The lack of a relationship between trust in alNahda and concerns about democracy further supports this conclusion.

Overall, it is clear that the process of updating beliefs about democracy by youths in Egypt and Tunisia varied significantly. In Tunisia, concern remained more-or-less evenly spread across all segments of society. This outcome is perhaps due to the fact that the electoral outcome and transition process produced fewer clear winners or losers. However, it is clear that on the whole Tunisian youths became far more concerned about the potential problems of democracy regardless of their ideological or economic background.

In contrast, the process of updating in Egypt shared greater similarities to the processes observed in other transitioning countries. Likely, the clear-cut electoral outcome made clear the winners and losers from the transition process. Yet, as the process played out and support for the FJP-led government dropped precipitously, the situation proved

\footnotetext{
${ }^{43}$ Richard Rose, William Mishler, and Christian Haerpfer, Democracy and its alternatives: Understanding post-communist regimes, Baltimore: Johns Hopkins University Press, 1998.
} 
Table 6

OLS Regression with Support for Political Islam as Dependent Variable

\begin{tabular}{|c|c|c|c|c|}
\hline \multirow[b]{2}{*}{ Variable } & \multicolumn{2}{|c|}{ Egypt } & \multicolumn{2}{|c|}{ Tunisia } \\
\hline & $\begin{array}{c}2011 \\
n=304\end{array}$ & $\begin{array}{c}2013 \\
\mathbf{n}=\mathbf{2 2 4}\end{array}$ & $\begin{array}{c}2011 \\
n=293\end{array}$ & $\begin{array}{c}2013 \\
n=166\end{array}$ \\
\hline Higher Rating of National & 0.327 & 0.269 & 0.074 & 0.181 \\
\hline Economy & $(0.132)^{* * *}$ & $(0.181)$ & $(0.107)$ & $(0.197)$ \\
\hline Higher Rating of National & 0.012 & 0.358 & -0.006 & 0.169 \\
\hline Government & $(0.086)$ & $(0.116)^{* * * *}$ & $(0.089)$ & $(0.140)$ \\
\hline Government Eliminating & -0.089 & -0.095 & 0.080 & -0.006 \\
\hline Corruption & $(0.129)$ & $(0.124)$ & $(0.104)$ & $(0.134)$ \\
\hline Higher Trust in the & 0.068 & 0.392 & 0.323 & 0.349 \\
\hline FJP/alNahda & $(0.079)$ & $(0.132)^{* * * *}$ & $(0.068)^{* * *}$ & $(0.125)^{* * *}$ \\
\hline Higher Rating of Last & & 0.085 & & 0.129 \\
\hline Parliamentary Election & & $(0.088)$ & & $(0.122)$ \\
\hline \multirow[t]{2}{*}{ Rural } & 0.270 & 0.367 & 0.193 & 0.529 \\
\hline & $(0.192)$ & $(0.195)^{*}$ & $(0.172)$ & $(0.266)^{* *}$ \\
\hline \multirow[t]{2}{*}{ Higher Education } & -0.200 & 0.311 & -0.140 & -0.313 \\
\hline & $(0.201)$ & $(0.297)$ & $(0.166)$ & $(0.269)$ \\
\hline \multirow[t]{2}{*}{ Higher Income } & -0.257 & -0.285 & 0.166 & 0.155 \\
\hline & $(0.109)^{* *}$ & $(0.110)^{* * * *}$ & $(0.081)^{* * *}$ & $(0.123)$ \\
\hline \multirow[t]{2}{*}{ Female Sex } & 0.323 & 0.096 & -0.037 & 0.132 \\
\hline & $(0.184)^{*}$ & (0.196) & $(0.152)$ & $(0.250)$ \\
\hline \multirow[t]{2}{*}{ Older Age } & -0.042 & -0.058 & -0.013 & 0.023 \\
\hline & $(0.028)$ & $(0.030)^{*}$ & (0.023) & $(0.036)$ \\
\hline
\end{tabular}

Note: Table presents coefficient $(\beta)$ estimates with standard errors in parentheses.

${ }^{*}$ Statistically significant at .1 level. ${ }^{* *}$ Statistically significant at .05 level. ${ }^{* * *}$ Statistically significant at .01 level.

dynamic. Unlike in Tunisia, concern about democracy in Egypt appears more closely related to the direct benefits and costs of this system to specific groups.

\section{Political Islam}

The same set of independent variables was run with support for political Islam as the dependent variable. Results in table 6 share some striking similarities to those for concern about democracy, although there are a number of important differences.

In Egypt in 2011, personal economic circumstances were strongly linked to support for political Islam. Among youths from poorer backgrounds, support for political Islam was higher than for others. This result suggests that many of Egypt's poorer youths, who at the time were also less concerned about potential problems associated with democracy, believed that political Islam might be the ideology that would best address issues related to social justice. Yet, controlling for economic circumstance, youths who said that the national economy was doing better were more likely to support political Islam. This 
apparent contradiction may be linked to benefits received from the Islamist social network throughout Egypt. ${ }^{44}$ Alternatively, it may be that those who are most concerned about the economy are less likely to support political Islam, given that Islamist parties are less likely to offer a clear economic platform or win support on this basis. ${ }^{45}$

A counterintuitive finding is that trust in the Muslim Brotherhood is not significantly related with support for political Islam. As the primary Islamist organization in Egypt, it would be expected that these two variables are closely related. Moreover, in 2011, trust in the Muslim Brotherhood was linked to attitudes about democracy, making this result even more surprising.

However, by 2013, the determinants of support for political Islam had shifted, as expected. After more than a year under an Islamist government, Egyptian youths appear to have revised their views based on their experiences. Again, a key determinant of support for political Islam was class: poorer Egyptian youth remained more likely to support political Islam compared with those who were better off.

However, similar to the first model, views of the national economy are not significant in explaining support for political Islam in 2013. Instead, satisfaction with government performance is a much stronger predictor. As expected, those who say the FJP-led government was doing a better job are also more likely to support political Islam.

Additionally, as expected, levels of trust in the Muslim Brotherhood are related to support for political Islam in 2013, with trust in the Muslim Brotherhood being positively correlated with support for political Islam. Among demographic variables, men remained more likely to support political Islam than women, while support for political Islam became more concentrated in rural areas relative to urban areas.

Overall, youth support for political Islam in Egypt became divided based on views of the Morsi government: those with favorable views of this political system remained committed to political Islam. Although poorer Egyptians remained more supportive of political Islam, the main dividing line became government policy. In other words, Egyptian youth made clear judgments about political Islam based on the FJP government and changed (or maintained) their beliefs accordingly.

\section{Tunisia}

Determinants of support for political Islam in Tunisia also show striking similarities with support for democracy. For example, in 2011, economic status is linked with support for political Islam. Somewhat surprisingly, given Tunisian political culture, youths from somewhat wealthier families are more likely to support political Islam than are their

\footnotetext{
${ }^{44}$ Janine Clark, Islam, Charity, and Activism: Middle-Class Networks and Social Welfare in Egypt, Jordan and Yemen, Bloomington, IN: Indiana University Press, 2004.

Tarek Masoud, Counting Islam, Cambridge: Cambridge University Press, 2014.

Steven Brooke, "Assumptions and Agendas in the Study of Islamic Social Service Provision." Project on Middle East Political Science Volume on Islamist Social Services, 2014.

${ }^{45}$ Michael Robbins, Bound by Brand: Opposition party success under electoral authoritarianism, Ph.D. Thesis, Department of Political Science, University of Michigan, 2012.
} 
poorer counterparts, a correlation potentially linked to the strength of Islamist movements among the middle classes. ${ }^{46}$ Meanwhile, other judgments about the economic or political factors have relatively little explanatory power for this dependent variable.

The model also reveals that views of alNahda, the main Islamist movement, are strongly linked to attitudes toward political Islam. Youths who trust alNahda are far more likely to support political Islam, compared with those who have lower levels of trust. Other demographic factors offer little explanatory power in terms of support for political Islam. Both men and women, more and less educated, and youths in urban and rural areas were about as likely to support political Islam after the 2011 Jasmine Revolution.

As with concern about democracy, the determinants of support for political Islam in Tunisia did not change dramatically between 2011 and 2013. Trust in alNahda remained a strong predictor of support for political Islam, suggesting that youths continued to view the movement and the ideology through a similar lens.

By 2013, class differences were no longer a significant predictor of support for political Islam; youths from wealthier and poorer backgrounds about equally likely to support political Islam. Notably, unlike Egypt, judgments about the performance of the government were not strongly linked with support for political Islam. Tunisian youths made fewer judgments about this ideology based on government performance, perhaps due to the fact that alNahda formed a broader coalition government. Meanwhile, no other economic or political variable was strongly linked with support for political Islam, further suggesting that political developments had limited effect on how Tunisian youths evaluated political Islam.

Among the demographic variables, youths in rural areas were somewhat more likely to support political Islam than those in urban areas. However, there were no differences between men and women, or those with higher or lower levels of education.

\section{Discussion}

The results from the above multivariate analysis suggest stark differences in how youths in Egypt and Tunisia changed their beliefs in response to the political changes taking place. The results in Egypt suggest a more dynamic process with youths from different backgrounds reevaluating their views toward both democracy and political Islam. At the time of the uprising, class was a major factor determining views of both democracy and political Islam. Youths who were better off, and presumably had greater connections to the former regime, remained far more concerned about democracy and less supportive of political Islam than their poorer counterparts. It appears that factors related to the expected personal costs and benefits of a more democratic system with a

\footnotetext{
${ }^{46}$ Janine Clark, Islam, Charity, and Activism: Middle-Class Networks and Social Welfare in Egypt, Jordan and Yemen, Bloomington, IN: Indiana University Press, 2004. Tarek Masoud, Counting Islam, Cambridge: Cambridge University Press, 2014.
} 
presumed electoral victory for Islamists strongly drove opinions of Egyptian youths during this period.

The process of updating attitudes between 2011 and 2013 reveals a similar pattern. Views of Morsi's government strongly impacted levels of concern about both democracy and support for political Islam. The data suggest that many Egyptian youth changed their attitudes by making judgments based the immediate results from the political transition.

The ultimate result of these changing views was not against democracy, but rather against political Islam. Despite the shifting views, support for democracy, and concerns about democracy, remained more-or-less constant between the two ways. In contrast, overall support for political Islam declined dramatically. The results suggest that Egyptian youth blamed the Islamist government for the failures of the political transition to a far greater extent than the process of democracy itself. Likely, the dominant position of the Muslim Brotherhood following parliamentary and presidential elections resulted in a decline in support among less partisan youth; the most loyal core of Brotherhood supporters remained supportive of political Islam, while support among other youths declined.

In contrast, attitudes in Tunisia toward both democracy and political Islam in Tunisia remained far more consistent between 2011 and 2013. Although, like Egypt, the opinions of youths varied by class shortly after the revolution, no such differences were evident two years after the Jasmine Revolution. In fact, one of the significant surprises of Tunisia is that youth, regardless of their socio-economic position or views of the government's performance, hold more-or-less similar views about problems associated with democracy as well as political Islam. Notably, youths do not appear to blame the challenges encountered during the transition on alNahda or the ideology it represents.

Overall, the shifts in opinion found in Tunisia indicate a change for nearly all segments of society. Given that support for political Islam remained essentially constant between 2011 and 2013, it appears that Tunisian youths did not attribute the challenges of the transition to alNahda and its ideology. Instead, Tunisia's youth became significantly more concerned about problems associated with democracy. However, unlike Egypt, this frustration was found throughout major ideological and demographic groups in society. Despite this growing concern, most Tunisian youths continued to say democracy remained the best system, despite its problems. Thus, the process of updating among youths in Tunisia is consistent with learning about the democratic process and updating opinions accordingly.

\section{Conclusion}

In early 2011, Tunisia and Egypt proceeded on somewhat similar paths. In both countries, mass protests led to the fall of long-standing authoritarian leaders. Relatively short transitional periods were followed by democratic elections where the primary Islamist party won the largest vote share. By 2013, both Islamist parties remained in power, providing youths in both countries with their first experience living under governments led by parties that take up the banner of Islam who were elected in free and fair elections. 
Despite these similarities, lessons about democracy and political Islam varied among youths in each country. Perhaps due to the dominant political position of the FJP in controlling both parliament and the presidency, Egyptians ages 18-29 judged the transition largely through a lens of political Islam. By 2013, judgments about both democracy and political Islam centered on the performance of the government and views of the Muslim Brotherhood itself, and were also divided along class lines. The failure of the FJP to work with other parties or share power appears to have divided Egyptian youth based on their partisan views. In other words, the apparent electoral strength of the FJP also became its greatest weakness. Youths pinned the major problems associated with the transition on the Brotherhood, as evidenced through a substantial decline in support for political Islam. Meanwhile, support for democracy remained more or less constant, measured both by general support and the degree to which youth had concerns about this type of system.

The experience in Tunisia could not have been starker. The transition under alNahda, which shared power with two other secular parties in the Troika government, resulted in fewer divisions among Tunisian youth. The broader coalition government appears to have resulted in fewer judgments about the government itself translating into changes in support for democracy or political Islam. Instead, frustration with the design of a democratic system, which often appeared slow to act, frustrated a significant share of Tunisian youth. Thus, concerns about democracy increased dramatically among all segments of the youth population. Nevertheless, likely cognizant that the previous regime was also unable to solve the country's basic problems, generalized support for democracy did not decline dramatically during this period.

These two cases have significant implications for the literature on political transitions and changes in support for democracy. After 1989, the existing literature argued that support for democracy depended primarily on economic conditions. ${ }^{47}$ In countries where economic conditions were better, support for democracy remained higher. Similarly, within country variation showed a similar pattern - those citizens who were better off or more advantaged by the new economic conditions remained more supportive of democracy.

The literature on the transitions in Sub-Saharan Africa in the 1990s focused instead on political institutions in understanding changes in support for democracy. In these cases, perceptions of political institutions including the electoral law and the nature of government institutions after the election have a major effect on levels of support for democracy. ${ }^{48}$ In cases where electoral processes were perceived as fair and the new

\footnotetext{
${ }^{47}$ Richard Rose, William Mishler, and Christian Haerpfer, Democracy and its alternatives: Understanding post-communist regimes, Baltimore: Johns Hopkins University Press, 1998.

${ }^{48}$ Michael Bratton, Robert Mattes, and Emmanuel Gyimah-Boadi, Public Opinion, Democracy, and Market Reform in Africa, Cambridge: Cambridge University Press, 2005.

Michael Bratton and Robert Mattes, "Learning about Democracy in Africa: Awareness, Performance and Experience," Afrobarometer Working Paper No. 31, 2003.

Devra Moehler, "Free and Fair or Fraudulent and Forged: Elections and legitimacy in Africa," Afrobarometer Working Paper No. 55 (December), 2005.
} 
government built more inclusive institutions that included representation from multiple key segments across society, citizens were more likely to maintain a higher level of support for democracy.

The findings from Tunisia and Egypt differ starkly from these previous cases. The pattern also differs from that found in Eastern Europe as, although economic conditions remained poor in both countries, Tunisian youth became far more critical of democracy during this period than their Egyptian counterparts. Meanwhile, the lessons from Sub-Saharan Africa do not hold in these cases either. In Tunisia, alNahda formed a coalition government that included two secular parties. Nevertheless, Tunisian youth became more critical of democracy in the aftermath of the revolution. In Egypt, where Islamists dominated the government, support for democracy nevertheless remained high among the youth population. These outcomes are the reverse of what would be expected based on the literature from the African cases.

These results suggest that the parties themselves have a more central role in explaining support for democracy than in the past. Further research is necessary to fully understand the reasons for this difference. One possibility is that with greater information available about the parties themselves in a world of social media, youth in Tunisia and Egypt look more to the parties than to the system itself. However, if true, then this pattern should be universal and could be validated by comparing transitions cases from other regions that share a temporal element.

A second important implication of this article is the primacy of domestic over international politics in explaining the opinions of youth. In the aftermath of the Arab uprisings, it was common to think that given the shared language and media channels across the region, international factors may have a significant influence. ${ }^{49}$ However, in both Egypt and Tunisia, youth appear to have changed their beliefs in response to the changes taking place in their domestic political system rather than events in other countries. Although coverage of events related to democracy and political Islam from across the Arab world were widely available to youths through

\footnotetext{
${ }^{49}$ Henry E. Hale, "Regime Change Cascades: What we have learned from the 1848 revolutions to the 2011 Arab uprisings," Annual Review of Political Science 16(2013): 331-353.

Michael Herb, "The People Want to Fall of the Regime...or Not: Explaining the diffusion of the Arab Spring," Georgia State University, May 21, 2014.

Marc Lynch, The Arab Uprising: The unfinished revolutions of the new Middle East. New York: PublicAffairs, 2013.

Justus Bamert, Fabrizio Gilardi, and Fabio Wasserfallen, "Learning and the diffusion of regime contention in the Arab Spring," Research \& Politics 2(2015): 1-9.

Michael Robbins and Mark Tessler, "The Effect of the Arab Spring on Support for Democracy: Evidence from an unplanned quasi-experiment," Paper presented at annual meetings of the American Political Science Association, New Orleans, August 30-September 2, 2012.

Stephen M. Saiderman, "When Conflict Spreads: Arab Spring and the limits of diffusion." International Interactions: Empirical and Theoretical Research in International Relations 38(2012): 713-722.
} 
satellite television or social media, the different nature of responses by youth in Egypt and Tunisia implies domestic events played the decisive role in changing their attitudes democracy and political Islam; the political learning process for Egyptian and Tunisian youth reflects events in their own country to a far greater extent than events across the region. 